\title{
Factors That Motivate the Use of IT Outsourcing in Thailand
}

\author{
Thipchutar Paparwekorn, Navneet Madan, Settapong Malisuwan, and Wassana Kaewphanuekrungsi
}

\begin{abstract}
IT outsourcing is the subcontracting of previous in-house IT activities to external IT vendors who can do them better and more efficiently because they possess higher resources and expertise. This study seeks to research on factors that motivate IT outsourcing in Thailand and the significance of each factor. The conceptual framework is presented and it is suggested that four factors, which are core business factor, technology factors, expertise, reliability and quality factors, and cost savings factors, play an important role in motivating firms to do IT outsourcing. The research conducted utilized one sample t-test to prove that each factor positively influences IT outsourcing. The results concluded that all four factors positively influence IT outsourcing of which core business factor and expertise, reliability and quality factors are the most important factors. This paper also concludes that contrary to the U.S and the U.K where cost the savings factor is the most significant, Thailand's most significant motivating factor for IT outsourcing is for it to be able to focus on its core business. Lastly, this research also provides several major recommendations that IT outsourcers must acknowledge and implement.
\end{abstract}

Index Terms-Outsourcing, IT outsourcing, total outsourcing, selective outsourcing.

\section{INTRODUCTION}

A new competitive landscape has resulted largely from continuous extreme technological advancements and increasing globalization. At present organizations are finding it almost impossible to sustain a competitive advantage or to move ahead of competitors within their industry [1]-[2]. In fast moving industries (fast industry clockspeed) [3]-[4], resources, capabilities and core competencies in the firm's internal organization are the prime influence on the firms' performance and it will also increase its strategic competitiveness [5]. Capability of the firm is only valuable or can be a source of competitive advantage if it is rare, costly to imitate and not substitutable by competitors' or other companies' resources [2], [5]-[8]. Over time, such capabilities must be developed and supported whether it is by investing financial or nonfinancial resources to build it into a core competency [5], [9]-[10]. Therefore, firms must choose to invest in activities and capabilities that are at the core of the business [5], [8],

Manuscript received April 9, 2013; revised June 20, 2013. This work was supported in full by National Broadcasting and Telecommunications Commission of Thailand.

Thipchutar Paparwekorn is with the Advanced Info Service, Bangkok, CO 10400 Thailand (e-mail: thipchutar@yahoo.com).

Navneet Madan, Settapong Malisuwan, and Wassana Kaewphanuekrungsi are with the National Broadcasting and Telecommunications Commission, Bangkok, CO 10400 Thailand (e-mail: navneet.m@nbtc.go.th, settapong.m@nbtc.go.th,wassana.k@nbtc.go.th).
[11]. The following framework illustrated in Fig. 1 should provide firms with guidance on when to do in-house capability building and when to conduct outsource.

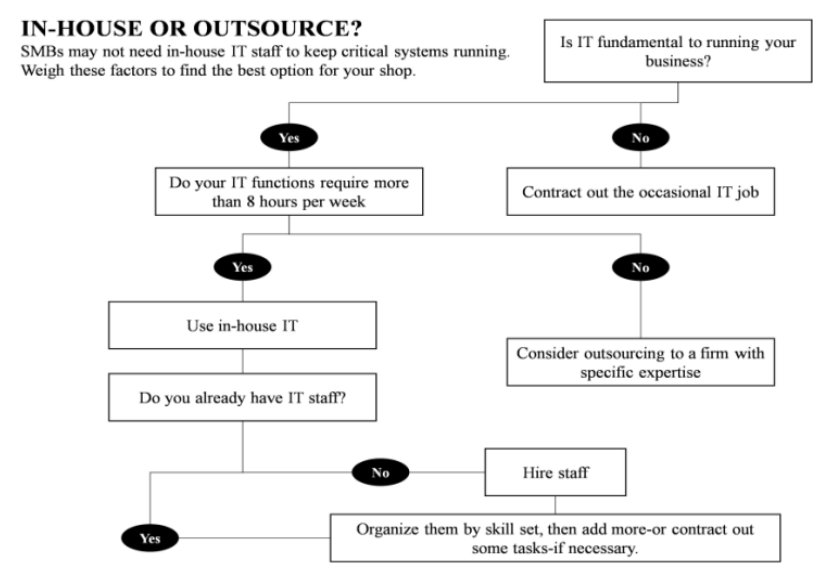

Fig. 1. In-house or outsource [12]

Despite countless literature advising firms to focus on core competencies [2], [5], firms still find it difficult because there are countless activities required by each firm to implement in order to support their core business [2], [9]. With this in mind, firms may find it more rational to outsource or purchase services from an external supplier who can do it better and more efficiently [11], [13]-[15]. Hitt et al., (2010) also supports this theory by stating that when firms perceive that they cannot afford to develop or perform a supporting activity internally, outsourcing is a better option [5], [11].

However, "firms must only outsource support activities where they cannot create value or where they are at a substantial disadvantage compared to competitors" [5]. As a rule, support activities can also play an imperative role in giving the organization a competitive advantage both directly and indirectly in a supporting role [2]. Especially technology development which is used in a supporting role is frequently critical to the firms' competitive advantage and if unavailable can be a substantial disadvantage to the firm [8], [16]. There is evidence that suggests business companies invest large amounts of money in IS/IT [17]. Gartner (2010) forecasts that IT spending of companies worldwide is expected to increase tremendously from 2011 to 2014 despite the global recession [18].

However, Fig. 2 illustrates that IT spending has been drowned in running the IT department. Since IT spending is largely used in running the IT department, little spending is left over to innovate IT activities that can grow or transform the business. In essence, most IT budgets drown in running the IT department rather than growing and transforming the business in a better way. Consequently, high costs of IT are 
proof why firms are motivated to outsource IT activities to economies of scale. IT efficient firms that can do more with less costs from

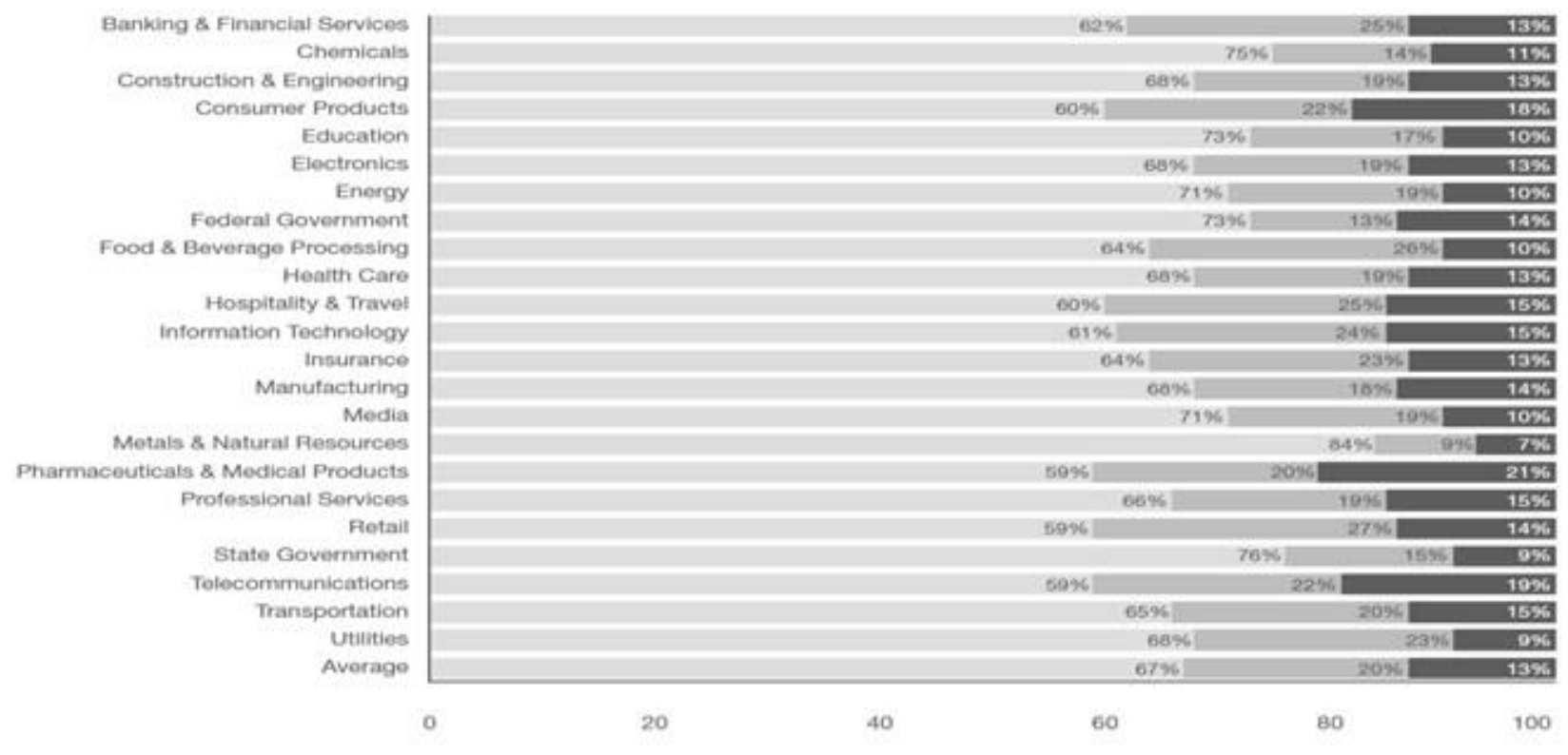

Fig. 2. IT spending to run, grow and transform the business $(2007)^{9}$

IT outsourcing is the subcontracting of previous in-house IT activities to external IT vendors who can do them better and more efficiently because they possess higher resources and expertise. Many companies today are outsourcing their IT because it requires a high investment, time and expertise. Organizations today cannot afford to spare investment, time and expertise unless it is the organizations' core business activity. Hence, companies are divesting supporting activities such as IT out to external vendors who can deliver greater results and with lower costs. IT outsourcing is therefore a strategic approach that enables organizations to address their information technology needs.

\section{LITERATURE REVIEW}

\section{A. Define Outsourcing}

Although the literature of "outsourcing" is quite wide and there are diverse definitions, each outsource definition is not enormously dissimilar from the other. With few differences, authors have defined outsourcing as the use of external firms to perform their internal organizational activity [19]. In order words, outsourcing can also be defined in simple terms as the subcontracting or permitting external companies to be responsible for specific activities or needs that the primary organization cannot or does not want to do [11], [15], [20]-[21]. ost schools of literature suggest that firms should not outsource core activities of their firm [2], [5], [11]. Nevertheless, there is increasing evidence that outsourcing services range from services that are unimportant and used infrequently to services that are imperative to core activity of the firm [19].

A research by Datamonitor confirms that the global market for outsourcing is extremely large and is expected to grow at a CAGR of $4.7 \%$ between 2007 to 2012 and the market is expected to reach value of $\$ 401.8$ billion [22]. About $87 \%$ of companies interviewed by KPMG have planned to maintain or increase their current outsourcing level [11]. Specifically, there has also been a wide range of opinions and facts on the growth of IT outsourcing. As suggested by Gonzales et al (2010), IT outsourcing is growing and will continue to be a

trend in this new millennium. Tan (2009) also verified that, IT outsourcing is expect to grow exponentially and was still growing in 2009 despite an expected crunch in investment during the financial crisis. As a result, this research seeks to research further into IT outsourcing since it is a growing and imperative investment for firms today.

Although this research provided a clear definition of outsource, we seek to further our research by defining IT outsourcing, factors motivating firms to do IT outsourcing and reasons to why firms are satisfied or dissatisfied with their IT outsourcing.

\section{B. Define IT Outsourcing}

As mentioned earlier, Furness (2007) has provided a definition of outsourcing which could also be applied to IT outsourcing. Therefore IT outsourcing should be defined as the subcontracting of previously in-house IT services or activities to an external organization [11], [20]-[21].

However, a more effective and thorough definition provided for IT outsourcing by Barthelemy and Geyer (2004) is

"The significant contribution by external vendors in the physical or human resources associated with the entire or specific component of the IT infrastructure in the user organization" [20].

IT outsourcing could also be defined as partial or total 
subcontracting of internal IT activities to an external agent. IT outsourcing can also be conducted in two ways. The first type is called selective outsourcing. Selective outsourcing is selection of certain IT functions or activities to be done externally by an external vendor [21]. In this case, the IT vendor will only assume responsibility for the functions outsourced to them [21]. The second type is total outsourcing. Total IT Outsourcing is the outsourcing of "functions, staff, assets and IT management of the organization to the external IT vendor" [21]. Companies are said to do total IT outsource when more than $80 \%$ of their IT budget is paid to the IT vendor [21].

\section{Risks of IT Outsourcing}

Despite the high risks, outsourcing is still experiencing a persistent growth [11], [15], [18]. Some of the risks of outsourcing include 1) the inability of firms to control the external vendor [21], 2) it could result in high cost draining if external vendor do not control costs, and finally [21], 3) external vendor could also provide bad quality and service performance [21], [23]. King and Malhotra (2000) extends that one other risk with outsourcing is the inability of the external organization to customize the IT services to the needs of the organization [19]. Above all, one other important risk that always results from outsourcing or even IT outsourcing is that there could be a high opportunity cost which could result from firms not developing IT capability internally, since IT can be a capability or asset that could result in competitive advantage to the firm if nurtured internally and a competitive disadvantage [14], [21] to the firm if not controlled appropriately.

Despite all the risks that result from outsourcing, literature still suggests that IT outsourcing is beneficial and it represents an opportunity market for outsourcers [15], [20], [21]. Benefits of IT outsourcing are explained in detail in the next section.

\section{Factors Motivating IT Outsource}

As explained above, there are diverse amount of reasons that motivate firms to do IT outsourcing. Although there are many negative effects of IT outsourcing, outsourcing also has many advantages that makes it a worthwhile option. Advantages of outsourcing are mentioned below.

\section{E. Strategic Focus or Focusing on Core Business}

Gupta and Gupta (1992) suggest that market challenges in fast moving industries or fast clockspeed industries [3] are forcing firms to cut out all irrelevant and insignificant business activities. Therefore, firms should eliminate all irrelevant activities and focus on core business and building core competencies [21]. IT operations can incur a huge amount of costs that could be avoided by inexperienced firms if they outsource. If IT services or business process is outsourced firms can focus their financial and nonfinancial resource in building their core competencies thereby resulting in competitive advantages [14].

H1: There is a significant positive relationship between "Strategic Focus or Focusing on Core Business" and the use of "IT Outsourcing"

\section{F. Technological Factor}

In recent years, there has been tremendous literature on fast and extreme technological changes which come in the form of radical innovations [24]. With extreme business environment volatility in our industrial markets, firms that are technologically incompetent or firms that do not have both financial and non-financial resources to support radical innovation are less likely able to react, respond or be proactive to such technological changes [11]. So, these firms can become technologically obsolete. Technological obsolescence is not being able to follow or catch up to current or updated technology. IT outsourcing comes into play by allowing technologically competent firms that can conduct IT activities in a suitable budget to conduct these activities for technologically incompetent organizations [21]. In this case, inexperienced firms do not have to tie up their resources, investment and staff in pursuing incremental changes in technologies. Experienced IT vendors can do it for them; thereby firms do not have to constantly drown its investment, staff time and other resources in pursuing a hard cause.

\section{1) Unavailability of technologically competent labour}

Emerging countries may lack certain advanced technologies and specialist staff who have know-how on these advanced technologies[23], [25]. Hence, this motivates companies to outsource abroad in countries that have these technological advances.

\section{2) Innovation and new ideas}

Organizational employees may think alike because they are exposed to organizational culture and thoughts [11], [23]. In the IT process, innovation is valued and there are many routes organizations can take to work efficiently. Unlike the organizations' own employees, IT vendors can provide an independent perspective and may have innovative ideas [11], [23]. Moreover, IT vendors may also have the know-how to innovate or the experience thus they can provide diverse ideas to improve IT processes in a cost efficient manner [11], [23].

H2: There is a significant positive relationship between "Technology" and the use of "IT Outsourcing"

\section{G. Quality, Expertise or Reliability}

Some organizations outsource because certain IT vendors have the know-how, capability or expertise to conduct IT services that the organization itself cannot implement. Such level of expertise required cannot be developed internally by the organizations in the short-term and therefore, there is no choice but to outsource to IT vendors that have this capability [21]. On the other hand, certain organizations also believe that their internal IT departments are unreliable and technically incompetent. Therefore, outsourcing to IT vendors can allow such organizations to have reliable IT services/processes even if IT cannot be implemented well internally [21].

Overall, factors that motivates firms to purchase IT outsourcing services are chiefly cost reduction, quality, innovation and in availability of labor and resources.

H3: There is a significant positive relationship between "Quality, Expertise or Reliability" and the use of "IT Outsourcing"

\section{H. Cost Savings}

Cost savings have been cited as the main reason for 
outsourcing in IT or IS outsourcing [19]. Firstly, IT vendors can afford to reduce costs for the primary organization because of economies of scale [11], [21]. It is more economical for organizations that require such IT expertise to do IT outsourcing because their staff may not have the technical training required to perform such activities economically or even with quality [21]. Secondly, most IT activities or processes require the firm to invest in hardware or software and this can result in huge fixed costs [26]. Such fixed costs can be avoided when the vendor already possesses such resources and so they charge these companies only for their services [21]. Thirdly, IT service fees provided to the IT vendor can be regarded as an operational or variable cost rather than a high capital expenditure [11]. Such costs do not result in a one-off cash sum thus, allowing more capital to be available for other core business functions [14], [21].

H4: There is a significant positive relationship between "Cost Savings" and the use of "IT Outsourcing"

\section{Satisfaction Rate Regarding IT Outsourced}

Regardless of the enormous and diverse advantages that IT outsourcing provides, Lacity and Willcocks (2001) found proof that companies in the U.S have experienced problems with IT outsourcing [23]. They quote that, "one-quarter of all respondents that they surveyed were encountering serious/difficult problems during outsourcing" [23]. Such organizations were dissatisfied and the reasons for dissatisfaction mainly resulted from bad quality, poor control, Increased IT costs, and so on. Chiefly, we could conclude that factors that motivated the firm to outsource were not achieved hence, firms were dissatisfied.

\section{J. IT Outsourcing in Thailand}

Unlike the U.S and the U.K who are developed countries, Thailand as an emerging or developing economy is perhaps motivated to do IT outsourcing with factors that are different from the U.S or the U.K. Shown in Table I, there is difference in percent of each factor that motivates IT outsourcing in the U.S and the U.K even though both countries are developed. We expect that the results of factors motivating Thai companies to do IT outsourcing could have a high variance from the U.S and the U.K since Thailand is a developing country with low human resource cost, hence cost reduction may not be the chief reason behind IT outsourcing as shown in Table I [23].

TABLE I: IT FACTORS OUTSOURCING MOTIVATION WITH UK AND US

\begin{tabular}{|l|c|c|c|}
\hline Actual Benefit & US $(\%)$ & UK $(\%)$ & A verage(\%) \\
\hline Cost reduction: & 40 & 64 & 53 \\
\hline Improved IT Flexibility & 46 & 36 & 41 \\
\hline Better quality service & 40 & 39 & 39 \\
\hline $\begin{array}{l}\text { Access to scarce IT } \\
\text { skills }\end{array}$ & 43 & 36 & 39 \\
\hline $\begin{array}{l}\text { Improved business } \\
\text { flexibility }\end{array}$ & 26 & 36 & 32 \\
\hline Focus on core business & 29 & 34 & 32 \\
\hline Access to new IT & 26 & 16 & 20 \\
\hline
\end{tabular}

As a result, this research focuses on factors motivating firms to do IT outsourcing in Thailand and whether the significance of each factors is much different than from developed countries. Hence, in Fig. 3, the conceptual framework of this research will be introduced.

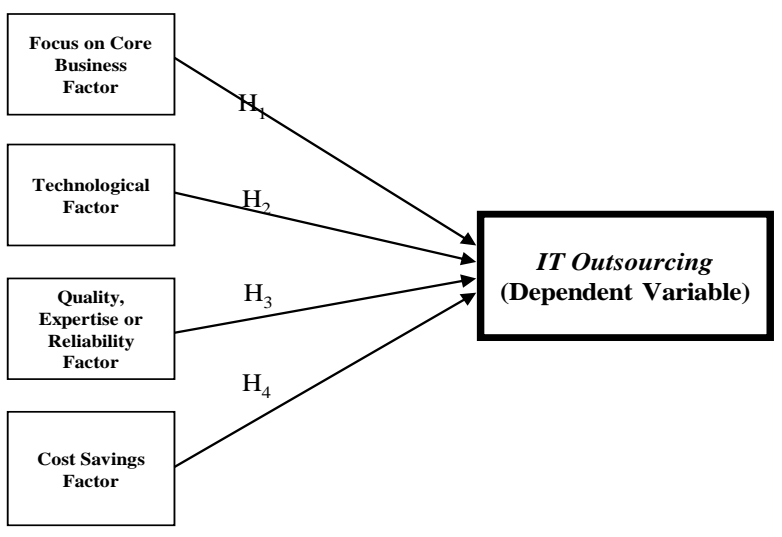

Fig. 3. The conceptual framework of IT outsourcing

\section{Methodology}

The purpose of this research is to test the theory from the literature review with companies in Thailand. Quantitative research is a structured and conclusive type of research. It is more appropriate in cases where a researcher wants to establish cause and effect relationships between variables [27]-[29]. Quantitative research involves a collection of numerical data and in most cases uses likert scale. It involves analyzing and interpreting numerical data with statistical software [30]. Furthermore, since this research is targeted specifically at firms who are doing IT outsourcing, it is a case study. This research will opt for a quantitative case study.

\section{A. Population and Sampling}

The target population of this research is information technology professionals, general managers or IS managers that are credible to answer questions regarding IT outsourcing. The respondent must have managerial responsibility for information systems and have knowledge regarding their companies IT activities or IT outsourcing of their organizations.

This research uses probability sampling where we called up companies who were already conducting IT outsourcing. We sent 400 questionnaires out in the mail and by email. Companies were called and reminded to do the surveys so that a high response rate could be achieved. 300 responses were achieved hence giving a response rate of $75 \%$.

\section{B. Data Collection and Research Instrument}

Data collection is achieved via means of a questionnaire survey. Most questionnaires were mailed to Thai organizations that required IT. Questionnaires mailed were in Thai and were translated by a professional translator. All questions were reviewed to ensure that the meaning did not change when it was translated. This is to ensure both validity and reliability. On the other hand, to ensure that most surveys could be collected, phone calls were conducted to ensure that the companies had received the surveys and they were requested to answer them. To increase motivation for companies to answer the survey, they were also promised a copy of the research so they could use the results of the discussion to identify the trends that motivate Thai companies to do IT outsourcing. 


\section{DATA ANALYSIS AND RESUlT}

The SPSS software for window is used for frequency analysis, reliability test, and the related analysis.

TABLE II: SELECTIVE OR TOTAL OUTSOURCING?

\begin{tabular}{|ll|r|r|r|r|}
\hline & & & & Cumulative \\
& & Frequency & Percent & Valid Percent & Percent \\
\hline Valid & Total outsource & 26 & 8.7 & 8.7 & 8.7 \\
& Selective outsource & 274 & 91.3 & 91.3 & 100.0 \\
& Total & 300 & 100.0 & 100.0 & \\
\hline
\end{tabular}

As shown in Table II, firms rarely do total outsourcing, and more than $90 \%$ of firms opt for selective outsourcing. Further research must be conducted to differentiate specifically what motivates firms to do "Total Outsource" and what motivate firms to do "Selective Outsource". This is to determine whether the factors that motivate these two types of IT outsourcing are significantly different.

\section{One Sample T-Test Analysis}

The hypotheses to be proven are provided below.

Hypothesis: There is a significant relationship between these "Factors" and the use of IT outsourcing.

1) H1: There is a significant positive relationship between "Strategic Focus or Focusing on Core Business" and the use of "IT Outsourcing"

2) H2: There is a significant positive relationship between "Technological Factor" and the use of "IT Outsourcing

3) H3: There is a significant positive relationship between "Quality, Expertise or Reliability" and the use of "IT Outsourcing"

4) H4: There is a significant positive relationship between "Cost Savings" and the use of "IT Outsourcing"

Before a T-test is conducted it is quite useful to conduct the descriptive analysis to get the grip of the characteristics of each construct as shown in Table III. All items in all constructs have a mean of more than 3 while item 5 of expertise, quality and reliability factor which is , "Before your company outsources the IT activity, which level of technical skill do your employees have in performing the activity?" has the highest mean of 4.07. Since this question was recoded to reverse the scale, it suggests most companies surveyed have employees with very low technical skill in performing the IT activity.

TABLE III: DESCRIPTIVE STATISTICS

\begin{tabular}{|l|r|r|r|r|}
\hline & $\mathrm{N}$ & Mean & Std. Deviation & $\begin{array}{c}\text { Std. Error } \\
\text { Mean }\end{array}$ \\
\hline Core Business Factor & 300 & 3.91333 & .79053 & .04564 \\
Technology Factor & 300 & 3.55867 & .76558 & .04420 \\
Expertise, Quality and Reliability Factor & 300 & 3.80714 & .69733 & .04026 \\
Cost Savings Factor & 300 & 3.67778 & .78296 & .04520 \\
\hline
\end{tabular}

Further it is important to clarify why a t-test was used in this case. A one sample t-test is used to evaluate whether a sample mean (of a normally distributed interval variable) significantly differs from a hypothesized value.

In this research, "a one-sample t-test" has been adopted to analyze whether each factor group mean is significantly different from the accepted value which in this case is more than 3 for a 5 likert scale.

Table IV presents t-statistics, mean difference and significance used to confirm the hypothesis. A one-sample ttest is used to evaluate whether all factors means are significantly different from 3 , the accepted mean from respondents who have perceived the importance of each factor group affecting IT outsourcing decisions in general.

TABLE IV: ONE SAMPLE T-TEST

\begin{tabular}{|c|c|c|c|c|c|c|}
\hline & \multicolumn{6}{|c|}{ Test Value $=3$} \\
\hline & \multirow[b]{2}{*}{$t$} & \multirow[b]{2}{*}{$d f$} & \multirow[b]{2}{*}{ Sig. (2-tailed) } & \multirow{2}{*}{$\begin{array}{c}\text { Mean } \\
\text { Difference }\end{array}$} & \multicolumn{2}{|c|}{$\begin{array}{l}95 \% \text { Confidence } \\
\text { Interval of the } \\
\text { Difference }\end{array}$} \\
\hline & & & & & Lower & Upper \\
\hline Core Business Factor & 20.011 & 299 & .000 & .91333 & .82351 & 1.00315 \\
\hline Technology Factor & 12.639 & 299 & .000 & .55867 & .47168 & .64565 \\
\hline Expertise, Quality and Reliability Factor & 20.048 & 299 & .000 & .80714 & .72791 & .88637 \\
\hline Cost Savings Factor & 14.994 & 299 & .000 & .67778 & .58882 & .76674 \\
\hline
\end{tabular}

H1: There is a significant relationship between "Strategic Focus or Focusing on Core Business Factor" and the use of "IT Outsourcing".

The one sample t-test proves that there is a mean difference of 0.9133 with a $p$ value of 0.000 . As a result, core business factor is significantly different from 3, suggesting that core business factors do motivate the use of IT outsourcing. There is a significant positive influence of core business factor on IT outsourcing.

$H 2$ : There is a significant relationship between "Technological Factor" and the use of "IT Outsourcing".

A one-sample t-test is used to evaluate whether the technological factor mean is significantly different from 3 . The sample mean of 0.56 is significant at $p$ value of 0.000 . Therefore, technology factors do have a small but positive influence on IT outsourcing in Thailand.

H3: There is a significant relationship between "Expertise, Quality and Reliability Factor" and the use of "IT Outsourcing".

A one-sample t-test is used to evaluate whether the expertise, quality and reliability factor means are significantly different from 3 . The sample mean of 0.807 is significant at $\mathrm{p}$ value of 0.000 . Therefore, expertise, technology and reliability do have a positive influence on IT outsourcing in Thailand.

H4: There is a significant relationship between "Cost Saving Factor" and the use of "IT Outsourcing"

A one-sample t-test was used to evaluate whether cost saving factor mean is significantly different from 3 . The sample mean of 0.68 is significant at p value of 0.000 . Therefore, cost saving do have a small but positive influence on IT outsourcing in Thailand.

\begin{tabular}{|l|c|}
\multicolumn{2}{|c|}{ TABLE V: HYPOTHESES } \\
\begin{tabular}{|l|c|}
\hline \multicolumn{1}{|c|}{ Hypotheses } & Research Result \\
\hline $\begin{array}{l}\text { Hypothesis 1: There is a significant positive } \\
\text { relationship between "Strategic Focus or } \\
\text { Focusing on Core Business" and the use of } \\
\text { "IT Outsourcing" }\end{array}$ & Supported \\
\hline $\begin{array}{l}\text { Hypothesis 2: There is a significant positive } \\
\text { relationship between "Technological }\end{array}$ & Supported \\
Factor"and the use of "IT Outsourcing" & Supported \\
\hline $\begin{array}{l}\text { Hypothesis 3: There is a significant positive } \\
\text { relationship between "Quality, Expertise or } \\
\text { Reliability" and the use of "IT Outsourcing" }\end{array}$ & Supported \\
\hline $\begin{array}{l}\text { Hypothesis 4: There is a significant positive } \\
\text { relationship between "Cost Savings" and the } \\
\text { use of "IT Outsourcing" }\end{array}$ & \\
\hline
\end{tabular}
\end{tabular}

\section{RESEARCH RESUlt}

Overall, as shown in Table $\mathrm{V}$, all factors have a positive 
influence on IT outsourcing. However, the mean difference of all factors does not exceed more than 1 suggesting that all factors are not extreme motivators of IT outsourcing in Thailand.

\section{Discussion, CONCLUSION AND RECOMMENDATION}

\section{A. Discussion}

Amongst all factors, the most important motivator to conduct IT outsourcing is focused on the core business activities factor. Gupta and Gupta (1992) suggests that market challenges in fast moving industries or fast clockspeed industries [3] are forcing firms to cut out all irrelevant and insignificant business activities. Firms therefore try to reduce time, resources and staffing of support activities to ensure that they can utilize their time, resources and staffing on building their core activities to a core competence instead. Amongst time, resources and staffing, results from this research have proven that firms are most highly motivated to outsource their IT activities to reduce company time spent on support activities. The second most significant factor that motivates firms to do IT outsourcing in Thailand is expertise, reliability and quality factor. As mentioned in the literature review Chapter 2, managers tend to perceive that IT outsourcing vendors are more likely able to implement the IT activities required better than normal firms can. This is because managers perceive them to be specialized and expert and thus they are more reliable and will deliver higher quality work. This is likely the case. The standard deviation for this factor is the lowest which proves that most managers' perception is less varied on this factor. Results also confirm that this is the second most important factor as to why firms conduct IT outsourcing in Thailand. The most important items in this factor that motivate IT outsourcing is that "the IT vendor has good after sales service to make sure they have given the organization quality work" and the company has an "IT vendor in mind who is credible and trustworthy". As a result, IT outsourcing vendors must ensure they seem credible and trustworthy within the market and also have good after sales services so that Thai companies are motivated to purchase their services. Thirdly, the third most important factor that motivates IT outsourcing is the cost savings factor. The literature suggests that cost savings is the most significant factor that motivates IT outsourcing in other countries including the US and the UK as shown in the table. This research suggests otherwise and results prove that Thai companies are not highly motivated by cost savings to conduct IT outsourcing but more likely motivated by saving time on supporting activities and focusing on building core competences instead. This is perhaps because as a developing country costs of staff and putting time on supporting activity is much lower than the costs faced by the US and the UK. However, further research must be conducted to confirm this statement. Additionally the most important point in cost savings factor is "IT outsourcing can reduce firms IT investment". Therefore, if firms truly believe and if IT outsourcing companies can reduce the firms' IT investment, firms may slightly be motivated to purchase IT outsourcing services from the IT vendor. Lastly, the technology factor is not as significant as other factors in motivating firms to conduct IT outsourcing. The technology factor states that firms are motivated to do IT outsourcing because it needs complex technologies, newer innovative technologies that the firm cannot create or does not process, complex demand which leads to continuous change in technology and it does not access complex technological equipment. In Thailand the technology factor is unlikely the reason behind why firms do IT outsourcing. Perhaps, Thai companies focus on low cost products that do not require complex technologies; however, this must be confirmed with further research.

The Table VI also confirms that cost reduction is the most important factor for the US and the UK companies. However, this is different for Thai companies as focus on core business is the most important factor. However, access to new IT is not highly significant or important for the US, the UK and Thailand alike.

TABLE VI: DIFFERENCE IN \% OF FACTORS MOTIVATING EACH COUNTRY TO DO IT OUTSOURCING (ADAPTED FROM LACITY\&WILLCOCKS)

\begin{tabular}{|l|c|c|c|}
\hline \multicolumn{1}{|c|}{ Actual benefit } & US (\%) & UK (\%) & $\begin{array}{c}\text { Average } \\
(\%)\end{array}$ \\
\hline Cost Reduction & 40 & 64 & 53 \\
\hline Improved IT Flexibility & 46 & 36 & 41 \\
\hline Better Quality of Service & 40 & 39 & 39 \\
\hline Access to Scarce IT Skills & 43 & 36 & 39 \\
\hline Improved Business & 26 & 36 & 32 \\
\hline Flexibility & 29 & 34 & 32 \\
\hline Focus on Core Business & 26 & 16 & 20 \\
\hline Access to New IT & & & \\
\hline
\end{tabular}

\section{B. Conclusion}

This research seeks to prove 1) core business factors, expertise, reliability and quality factors, cost savings factors and technology factors positively influence or motivate firms to do IT outsourcing. 2) There is a difference in the extent of how each factor motivates IT outsourcing in Thailand and developed countries like the U.S and the UK.

Conclusively, the research results confirmed that all factors including core business factors, expertise, reliability and quality factors, cost savings factors and technology factors have a positive significant influence on IT outsourcing. This research also confirms that although the cost savings factor is the most important motivator for IT outsourcing in both the U.S and the UK, it is not the most important motivator to do IT outsourcing for Thai companies. However, the quest to have advanced technologies or more innovation is the least important motivating factor for both Thailand and developed countries like the U.S and the UK.

\section{Recommendation}

This research seeks to provide few recommendations to IT outsourcers. First, IT vendors should focus on learning all the IT activities of the organization it is servicing such that they do not have to spend excess time dealing with IT vendors than they should. Since focusing on core 
competencies is the most important factor to why firms conduct IT outsourcing, IT vendors may lose outsourcing contracts if they still require firms to spend a lot of time dealing with them and their quality of work is low. Secondly, firms who are motivated to conduct IT outsourcing also require IT vendors to have high expertise, credibility and trustworthiness. IT vendors should create a reputation that they can deliver quality work and hence they will be likely to attract IT outsourcing contracts from Thai companies. Ultimately, it is also recommended that foreign or even Thai IT vendors should understand that factors motivating IT outsourcing in Thailand and other countries are very different.

As a result, this research has proven that the same factors that positively influence IT outsourcing in the U.S and the UK also motivate Thai companies. However, this research has highlighted the significance of factors motivating IT outsourcing in Thailand in sequence. Therefore, IT vendors that take these recommendations and implement them are highly likely to increase their revenue.

\section{LIMITATION OF THE STUDY}

There is a limitation of this research. This research is based on Thai companies and the targeted population is Thai IT managers or general managers who understand why companies are conducting IT outsourcing. The area where this questionnaire was distributed was in Bangkok and the results may turn out different if the surveys were distributed in other provinces in Thailand.

\section{REFERENCES}

[1] J. Cronk and J. Sharp, "A framework for deciding what to outsource in information technology," Journal of Information Technology, vol. $10,2001$.

[2] B. Reimann, "Sustaining the competitive advantage," Strategy and Leadership, vol. 17, 1989.

[3] C. H. Fine, Clockspeed: Winning Industry Control in the Age of Temporary Advantage, Massachusetts: Perseus Books, 1998.

[4] R. K. Perrons and K. Platts, "The role of clockspeed in outsourcing decisions for new technologies: insights from the prisoner's dilemma," Industry Management and Data Systems, vol. 104, pp. 624-632, 2004.

[5] M. A. Hitt, R. D. Ireland, and R. E. Hoskisson, Strategic Management: Competitiveness and Globalization, Concepts and Cases, Cengage Learning, 2010.

[6] Hitt, Keats, and DeMarie, "Navigating in the new competitive landscape: building strategic flexibility and competitive advantage in the 21st century," Academy of Management Executive, vol. 12, pp. 22-42, 1998.

[7] J. Johnson, R. Lee, A. Saini, and B. Grohmann, "Market-focused strategic flexibility: conceptual advances and an integrative model," Journal of the Academy of Marketing Science, vol. 31, pp. 74-89, 2003.

[8] N. Pati and M. S. Desai, "Conceptualizing strategic issues in information technology outsourcing," Information Management \& Computer Security, vol. 13, pp. 281-296, 2005.

[9] G. Johnson, K. Scholes, and R. Whittington, Exploring corporate strategy, 7th enhanced media ed. ed. Harlow: FT/Prentice Hall, 2006.

[10] M. A. Hitt, B. W. Keats, and S. M. DeMarie, "Navigating in the new competitive landscape: building strategic flexibility and competitive advantage in the 21st century," The Academy of Management Executive, vol. 12, pp. 22-42, 1998.

[11] R. Gonzales, J. Gasco, and J. Llopis, "Information systems outsourcing reasons and risks: a new assessment," Industrial Management and Data Systems, vol. 110, no. 2, 2010.

[12] R. Morgan. "When to outsource it: find the right mix of internal and external staff for your company," PC Magazine, 2006.

[13] G. Southwood, "Outsourcing your Information Resources," Records Management Journal, vol. 5, pp. 101-113, 1995.
[14] R. Dreischmeier and D. Rhodes, IT Outsourcing Rediscovered: Getting Your Share This Time Around, 2006.

[15] V. Furness, Growth Opportunities and Markets for IT Outsourcing, 2007.

[16] A. M. Rugman and A. Verbeke, "Edith Penrose's Contribution to the Resource-Based View of Strategic Management," Strategic Management Journal, vol. 23, pp. 769-780, 2002.

[17] S. Clarke and N. Doherty, "The importance of a strong business-IT relationship for the realisation of benefits in e-business projects," Qualitative Market Research: An International Journal, vol. 7, pp. 58-66, 2004.

[18] R. Gordon, W. Hahn, and J. Lovelock, IT Spending Forecast, $3 Q 10$ Update:Where are the Opportunities in 2011 (And Beyond)? 2010.

[19] W. R. King and Y. Malhotra, "Developing a framework for analyzing IS sourcing," Information \& Management, vol. 37, pp. 323-334, 2000.

[20] J. Barthelemy and D. Geyer, "The determinants of total IT outsourcing: an empirical investigation of french and german firms," Journal of Computer Information Systems, 2004.

[21] D. Tan, "Factors related to it outsourcing result," Journal of Outscoring and Organisational Information Management, 2009.

[22] "The technology investment and outsourcing outlook: enterprise technology investment priorities," Datamonitor 360, 2008.

[23] T. Suzuki, "Globalization and IT outsourcing: the case of Japanese banks," USJP Occasional, pp. 5-12, 2005.

[24] L. Yuan, S. Zhongfeng, and L. Yi, "Can strategic flexibility help firms profit from product innovation?" Technovation, vol. 30, pp. 300-309, 2010.

[25] M. George, "Strategies for Offshore Outsourcing of Information Technology Work," ed, 2008.

[26] PWC, Why isn't IT spending creating more value?: How to start a new cycle of value creation, 2008.

[27] D. R. Cooper and P. S. Schindler, Business Research Methods, McGraw-Hill Higher Education, 2011.

[28] Parasuraman, Market Research: South-Western College Pub, 2nd edition, 2006.

[29] R. Johnson and A. J. Onwuegbuzie, "Mixed Methods Research: A Research Paradigm Whose Time Has Come," Educational Researcher, vol. 33, pp. 14-26, 2004.

[30] M. Frenz, K. Nielsen, and G. Walters, Research Methods in Management, London: Sage Publications, 2009.

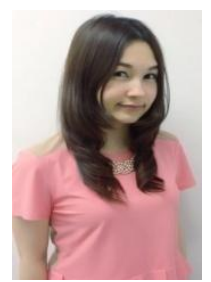

Thipchutar Paparwekorn received her bachelor of Liberal Arts from Sripatum University, Thailand, 2003, and MBA from Assumption University, Thailand, 2013. Her current research interests are in Brand management and Marketing Management. She is currently working as a senior marketing officer at Advance Info Services Public Company Limited (AIS), Thailand. She worked on several research projects in diverse fields such as media and internal media. managing all communication channels in both mass

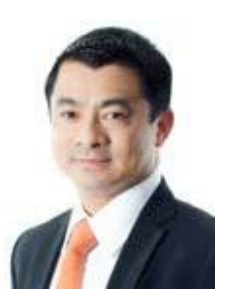

Settapong Malisuwan was born on March 24, 1966, in Bangkok, Thailand. He received his $\mathrm{PhD}$ in electrical engineering (telecommunications), specializing in mobile communication systems from Florida Atlantic University (State University System of Florida), Boca Raton in 2000. He received an MSc in electrical engineering in mobile communications system, from George Washington University in 1996, an MSc in electrical engineering in telecommunication engineering from Georgia Institute of Technology in 1992 and a BSc in electrical engineering from the Chulachomklao Royal Military Academy, Nakhon-Nayok, Thailand in 1990.

He served in the Royal Thai Armed Forces for more than 25 years and is currently the Vice Chairman of National Broadcasting and Telecommunications, Bangkok, Thailand. His research interests are in efficient spectrum management and Telecommunications policy and management in Thailand. Col.

Dr. Settapong Malisuwan is currently the Elected Vice Chairman and Board Member in the National Broadcasting and Telecommunications Commission, Thailand. 
Navneet K. Madan was born in Bangkok, Thailand on April 22, 1987. She received her Bachelor of Business Administration in international business management from Mahidol University in 2008, and received Master of Science degree in strategic management and marketing, Middlesex university, London, United Kingdom. She has been working as an Assistant to Vice Chairman in National Broadcasting and Telecommunications, Bangkok, Thailand since January 2012. Her research interests are in Spectrum Management Strategic Flexibility, Market Orientation and Environmental Uncertainty in Fast Clockspeed Industries.

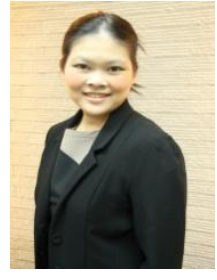

Wassana Kaewphanuekrungsi was born on February 1st, 1979, Bangkok, Thailand. She received her B.S. in Statistics from Chulalongkorn University, Thailand, 2000, and M.S. in Technology Management from Thammasat University, Thailand, 2006. She joined National Broadcasting and Telecommunication Commission (NBTC) as an Assistant to Vice Chairman of NBTC in December 2011. Previously in 2010, she worked as senior system analyst in Bangkok Insurance (Public) Co., Ltd. Her research interests are in telecommunication technology, wireless communication and antenna design. 